\title{
Antimicrobial activity, acute toxicity and cytoprotective effect of Crassocephalum vitellinum (Benth.) S. Moore extract in a rat ethanol-HCl gastric ulcer model
}

\author{
Mainen J Moshi ${ }^{1 *}$, Ramadhani SO Nondo ${ }^{1}$, Emmanuel E Haule ${ }^{1}$, Rogasian LA Mahunnah ${ }^{2}$ and Abdul W Kidukuli ${ }^{1}$
}

\begin{abstract}
Background: A decoction of Crassocephallum vitellinum (Benth.) S. Moore (Asteraceae) is used in Kagera Region to treat peptic ulcers. This study seeks to evaluate an aqueous ethanol extract of aerial parts of the plant for safety and efficacy.

Methods: An 80\% ethanolic extract of C. vitellinum at doses of 100, 200, 400 and $800 \mathrm{mg} / \mathrm{kg}$ body wt was evaluated for ability to protect Sprague Dawley rats from acidified ethanol gastric ulceration in comparison with $40 \mathrm{mg} / \mathrm{kg}$ body wt pantoprazole. The extract and its dichloromethane, ethyl acetate, and aqueous fractions were also evaluated for acute toxicity in mice, brine shrimp toxicity, and antibacterial activity against four Gram negative bacteria; Escherichia coli (ATCC 25922), Salmonella typhi (NCTC 8385), Vibrio cholera (clinical isolate), and Streptococcus faecalis (clinical isolate). The groups of phytochemicals present in the extract were also determined.

Results: The ethanolic extract of $C$. vitellinum dose-dependently protected rat gastric mucosa against ethanol/HCl insult to a maximum of $88.3 \%$ at $800 \mathrm{mg} / \mathrm{kg}$ body $\mathrm{wt}$, affording the same level of protection as by $40 \mathrm{mg} / \mathrm{kg}$ body wt pantoprazole. The extract also exhibited weak antibacterial activity against S. typhi and E. coli, while its ethyl acetate, dichloromethane and aqueous fractions showed weak activity against K. pneumonia, S.typhi, E. coli and V. cholera. The extract was non-toxic to mice up to $5000 \mathrm{mg} / \mathrm{kg}$ body $\mathrm{wt}$, and the total extract $\left(\mathrm{LC}_{50}=37.49 \mu \mathrm{g} / \mathrm{ml}\right)$ and the aqueous $\left(\mathrm{LC} \mathrm{C}_{50}=87.92 \mu \mathrm{gg} / \mathrm{ml}\right)$, ethyl acetate $\left(\mathrm{LC}_{50}=119.45 \mathrm{\mu g} / \mathrm{ml}\right)$ and dichloromethane fractions $(88.79 \mu \mathrm{g} / \mathrm{ml})$ showed low toxicity against brine shrimps. Phytochemical screening showed that the extract contains tannins, saponins, flavonoids, and terpenoids.

Conclusion: The results support the claims by traditional healers that a decoction of C.vitellinum has antiulcer activity. The mechanism of cytoprotection is yet to be determined but the phenolic compounds present in the extract may contribute to its protective actions. However, the dose conferring gastro-protection in the rat is too big to be translated to clinical application; thus bioassay guided fractionation to identify active compound/s or fractions is needed, and use of more peptic ulcer models to determine the mechanism for the protective action.
\end{abstract}

Keywords: Crassocephalum vitellinum, Traditional medicine, Gastric cytoprotection, Antimicrobial, Acute, Toxicity

\footnotetext{
* Correspondence: mmoshi@muhas.ac.tz

${ }^{1}$ Department of Biological and Preclinical Studies, Muhimbili University of

Health and Allied Sciences, P.O. Box 65001, Dar es Salaam, Tanzania

Full list of author information is available at the end of the article
} 


\section{Background}

The Kagera region has a culture rich in traditional medicine practice, but the majority of plants used in this region are poorly documented and have not yet been evaluated for safety and efficacy. Crassocephallum vitellinum (Benth.) S. Moore (ASTERACEAE); Synonym: Gynura vitellina Benth is among plants used in Bukoba for the treatment of peptic ulcer disease [1]. The aerial parts of $C$. vitellinum are boiled with water and the resulting decoction is taken regularly for management of peptic ulcers [1]. Reports from other areas show that in Kenya the plant is used for the treatment of stomach complications, malaria and mouth infections in children [2], while in Zaire the leaves are burnt with those of the cultivated yam and the ash is applied to scarifications for the treatment of swollen legs [3]. In Southern Rwanda C.vitellinum is used as a hepatoprotective remedy which has eventually been linked to its antioxidant properties $[4,5]$. An extract of the plant protected rats against acetaminophen induced liver toxicity, and in addition it reversed barbiturate induced sleep in guinea pigs [4]. The leaves are used for the treatment of female sterility, strong fever, dysmenorrhea, constipation, childhood diseases and facilitate the deliverance of placenta [4]. The filtrate of crushed leaves and flowers of the plant combined with those of Plantago palmata Hoof.f., Vernonia auriculifera Hiern and Physalis peruviana L. is used for treatment of whooping cough [6], while the leaves are used for management of anorexia [7] and for antenatal care [8]. The leaves are used in veterinary medicine for treatment of mastitis, fever, and to facilitate lactation and activity has been linked to the flavonoid content of the leaves [9]. The antioxidant and antibacterial activity of the essential oils of the aerial parts of the plant was recently reported [10]. In refugee camps in Tanzania, traditional healers use the leaves of $C$. vitellinum for constipation and abortion [11].The leaves are also used by the Haya people to treat gonorrhea [1].

This study was done to evaluate the efficacy of an extract of the aerial parts for protection against acidified ethanol induced gastric ulceration in Spague Dawley rats. The extract was also tested for antibacterial activity. Phytochemical screening was done to determine the groups of compounds present in the extract, while acute toxicity in mice and brine shrimp lethality test were done to determine safety of the extract.

\section{Methods}

\section{Materials}

Tryptone Soya broth was purchased from HIMEDIA ${ }^{\oplus}$ (Himedia Laboratories Pvt Ltd, Mumbai, INDIA; $p$-Iodonitrotetrazolium chloride (INT) from SIGMA ${ }^{\circ}$ (SigmaAldrich $^{\oplus}$, St Louis, USA); pantoprazole (lyophilized powder for i.v injection; Batch No. JKJ 3534D and manufactured by Sun Pharmaceutical Industries Ltd, Halol-Baroda Highway,
Halol-389350, Gujarat, India.), was sourced from a local pharmacy. Ethanol (absolute) was purchased from Fluka Chemie GmbH (Sigma-Aldrich ${ }^{\oplus}$, Zwijndrecht, Netherlands), while dimethyl sulfoxide (DMSO) was purchased from Sigma ${ }^{\oplus}$ (Poole, Dorset, UK). Cyclophosphamide, NEOPHOS $500^{\circ}$ (CIPLA Ltd, MIDC Boisar, INDIA) was purchased from a local Pharmacy in Dar es Salaam, Tanzania. Escherichia coli (ATCC 25922), Salmonella typhi (NCTC 8385), Vibrio cholerae (clinical isolate), and Klebsiella pneumoniae (clinical isolate) were obtained from the Department of Microbiology and Immunology, Muhimbili University of Health and Allied Sciences (MUHAS). The brine shrimp eggs were bought from Aquaculture Innovations (Grahamstown 6140, South Africa) and sea salt was prepared locally by evaporating water collected from the Indian Ocean, along the Dar es Salaam Coast.

\section{Collection of plant material}

The aerial parts of Crassocephallum vitellinum (Benth.) S. Moore (ASTERACEAE) were collected by an experienced botanist, Mr. Haji O. Selemani of the Department of Botany, University of Dar es Salaam and voucher specimen no. MH 164569 is kept at the Herbarium of the Institute of Traditional Medicines, Muhimbili University of Health and Allied Sciences.

\section{Preparation of plant extracts}

The air-dried plant material was ground into powder using a plant milling machine. The plant material was macerated in $80 \%$ ethanol at room temperature for $24 \mathrm{~h}$ and filtered through Whatman No.1 filter paper. This procedure was repeated 3 times to ensure complete extraction of plant material. The pooled extract was concentrated by evaporation under reduced pressure in a rotary evaporator at $40{ }^{\circ} \mathrm{C}$. The extract yield was $31 \mathrm{~g}$ from $292 \mathrm{~g}$ of dry plant material (10.62\%).

\section{Testing for antiulcer activity}

Both male and female Sprague Dawley rats weighing 100-188 g were used. The rats were fasted for $36 \mathrm{~h}$ but allowed free access to drinking water. Thirty rats were randomly allocated to 5 groups of 6 rats each. The rats in group one (Solvent control) were pre-dosed orally with $5 \mathrm{ml} / \mathrm{kg}$ body wt of $1 \%$ tween 80 in normal saline; rats in group two were pre-dosed orally with $40 \mathrm{mg} / \mathrm{kg}$ body wt pantoprazole (Positive control), and rats in groups 3, 4 and 5 were pre-dosed orally with 200, 400 and $800 \mathrm{mg} / \mathrm{kg}$ body wt solution of $C$. vitellinum extract one hour before oral administration of $5 \mathrm{ml} / \mathrm{kg}$ body wt of the ulcerogenic mixture. The ulcerogenic mixture contained $80 \%$ ethanol, 5\% hydrochloric acid and 15\% distilled water. The animals were euthanized by ether anaesthesia $4 \mathrm{~h}$ after administration of acidified ethanol. The stomachs were removed, cut open along the greater 
curvature, washed with normal saline and observed for the severity of ulcers. The degree of ulceration (Ulcer index) was graded according to a method previously described by Shay and colleagues [12] as follows: $0=$ no lesions (normal stomach); $0.5=$ hyperemia (red coloration); 1 =hemorrhagic spots, $2=1-5$ small ulcers; $3=$ many small ulcers, $4=$ many small and large ulcers; $6=$ stomach full of ulcers along with perforations. Percentage protection was calculated by comparison with the untreated control group Percentage protection [12]

$$
=100-\frac{\text { Mean ulcer index of treated group }}{\text { Mean ulcer index of control group }} \times
$$

\section{Statistical analysis}

The results are expressed as mean \pm standard deviation (SD). The results of mean ulcer index were compared using the non-parametric Kruskal-Wallis test.

\section{Testing for antibacterial activity Test organisms}

Four Gram-negative bacteria (enterobactericeae) namely Escherichia coli, Salmonella typhi, Vibro cholera, and Klebsiella pneumonea were used, which were obtained from the Department of Microbiology and Immunology, Muhimbili University of Health and Allied Sciences.

\section{Determination of minimum inhibitory concentrations (MICs)} Minimum inhibitory concentrations (MICs) were determined using the microdilution method [13]. A stock solution of the extract was prepared by dissolving $100 \mathrm{mg}$ of the $80 \%$ ethanol extract into $1 \mathrm{ml}$ of DMSO $(100 \mathrm{mg} / \mathrm{ml})$. Each of the 96 well microtitre plates were first preloaded with $100 \mu \mathrm{l}$ of tryptic soya broth followed by addition of $100 \mu \mathrm{l}$ of the extract into the first wells of the rows to make a total volume of $200 \mu \mathrm{l}$ in the first wells. After thorough mixing $100 \mu \mathrm{l}$ were transferred from the first row wells into the next row wells. The process was repeated sequentially to the last well at the bottom where $100 \mu \mathrm{l}$ was discarded. Thereafter, $100 \mu \mathrm{l}$ of the bacterial suspension (0.5Mac Farland standard turbidity) was then added to each well to make a final volume of $200 \mu \mathrm{l}$ in each well. Gentamicin sulphate $(100 \mu \mathrm{g} / \mathrm{ml})$ was used as a standard drug. Rows containing broth, DMSO and bacteria were included as negative controls (solvent control) and rows containing broth and bacteria only were included in order to see whether there was bacterial growth or not (growth control). The plates were then incubated at $37^{\circ} \mathrm{C}$ for $24 \mathrm{~h}$. After incubation for $24 \mathrm{~h}$, at $37^{\circ} \mathrm{C}, 40 \mu \mathrm{l}$ of $0.02 \% \mathrm{p}$ iodonitrotetrazolium (INT) chloride solution was added to each well followed by incubation for $1 \mathrm{~h}$ at $37^{\circ} \mathrm{C}$. Bacterial growth was indicated by a change in color to pink in the wells. Absence of bacterial growth was indicated by no color change of the dye. The first concentration at which no bacterial growth occurred was taken as the MIC.

\section{Brine shrimps lethality test}

The brine shrimp lethality test (BST) was used to predict the presence, in the extract, of cytotoxic activity [14]. Solutions of the extract were made in DMSO at concentrations ranging from $8-240 \mu \mathrm{g} / \mathrm{ml}$ and incubated in duplicate vials with brine shrimp larvae. Ten brine shrimp larvae were placed in each of the duplicate vials. Control brine shrimp larvae were placed in a mixture of artificial sea water (3.8 g/l sea salt) and DMSO only. After $24 \mathrm{~h}$ the nauplii were examined against a lighted background, and the average number of live larvae in each duplicate vial was determined. The mean percentage mortality was plotted against the logarithm of concentrations and the concentration killing fifty percent of the larvae $\left(\mathrm{LC}_{50}\right)$ was determined from the graph [15].

\section{Data analysis}

The mean results of brine shrimp mortality against the logarithms of concentrations were plotted using the Fig $\mathrm{P}$ computer program (Biosoft Inc, USA), which also gives the regression equations. The regression equations were used to calculate $\mathrm{LC}_{16}, \mathrm{LC}_{50}$ and $\mathrm{LC}_{84}$ values. Confidence intervals $(95 \% \mathrm{CI})$ were then calculated using the three results $[14,15]$. An $\mathrm{LC}_{50}$ value greater than $100 \mu \mathrm{g} / \mathrm{ml}$ was considered to represent an inactive compound or extract.

\section{Acute toxicity test}

Acute toxicity was done according to OECD guidelines 425 [16]. Both male and female Theiller's original albino mice were used. The mice were acclimatized in an air conditioned room at $20^{\circ} \mathrm{C}$ for 7 days before experimentation. Before dosing with extracts the mice were starved for 18-24 h with access to adequate drinking water, in cages with wire mesh bottoms to prevent coprophagy. Initially a dose of $1000 \mathrm{mg} / \mathrm{kg}$ body wt was administered to a group of 6 mice (3 male and 3 female), and mice observed for signs of immediate toxicity and/or death for 72 h. If no toxicity was observed another group of 3 male and 3 female mice was given a dose of $2000 \mathrm{mg} / \mathrm{kg}$ body wt and the same observations made. If no signs of toxicity or death occurred doses were sequentially increased to 3000,4000 , and $5000 \mathrm{mg} / \mathrm{kg}$ body wt, respectively. Extracts were solubilized in 1\% tween 80 in normal saline and administered at a single dose volume of $5 \mathrm{ml} / \mathrm{kg}$ body wt or two doses of $5 \mathrm{ml} / \mathrm{kg}$ body wt depending on solubility, within a one hour interval. A control group was administered a single $5 \mathrm{ml}$ or $5 \mathrm{ml} / \mathrm{kg}$ body wt of $1 \%$ tween 80 twice to match with the dose of administered plant extract. 


\section{Phytochemical screening}

The $80 \%$ ethanol extract was tested for the presence of steroids, saponins, flavonoids, terpenoids, cardiac glycosides, alkaloids and tannins using standard methods $[17,18]$.

\section{Ethical clearance}

This study was given ethical clearance by the Muhimbili University of Health and Allied Sciences Institutional Review Board.

\section{Results}

\section{Antiulcer activity}

The $80 \%$ ethanol extract of $C$. vitellinum showed a dosedependent protection against ethanol/ $\mathrm{HCl}$ induced gastric ulceration. Table 1 shows that the extract protected the rat stomach from ulceration by $55 \%$ at a dose of $200 \mathrm{mg} / \mathrm{kg}$ body wt $(\mathrm{P} \leq 0.001)$ and this increased to $71.7(\mathrm{P} \leq 0.001)$, and $88.3 \%(\mathrm{P} \leq 0.001)$ at 400 and $800 \mathrm{mg} / \mathrm{kg}$ body wt as compared to solvent treated rats, respectively. This was the same percentage protection as $40 \mathrm{mg} / \mathrm{kg}$ body wt of the proton pump inhibitor, pantoprazole. Figure 1 shows that at $800 \mathrm{mg} / \mathrm{kg}$ body wt the stomach appeared similar to that of the rats pretreated with $40 \mathrm{mg} / \mathrm{kg}$ body wt pantoprazole. Figure 2 shows the dose-response relationship for control, 400 and $800 \mathrm{mg} / \mathrm{kg}$ body wt of the plant extract

\section{Antibacterial activity}

The results for antibacterial activity (Table 2) indicate that the total extract had weak activity against Salmonella typhi and Escherichia coli with MIC of $3.125 \mathrm{mg} / \mathrm{ml}$. When the extract was fractionated to aqueous, ethyl acetate and dichloromethane fractions the results show that the ethyl acetate fraction was active against the four bacteria used; i.e. K. pneumoniae, S. typhi, E. Coli and V. cholera, and was active against more bacteria than the total extract. Both the dichloromethane and ethyl acetate extracts had very weak activity against all the four bacteria used.

\section{Brine shrimp lethality test}

The brine shrimp test results (Table 3 ) show that generally the total extract $\left(\mathrm{LC}_{50}=37.49 \mu \mathrm{g} / \mathrm{ml}\right)$ and the aqueous, dichloromethane and ethyl acetate fractions all exhibited moderately low brine shrimp toxicity.

\section{Acute toxicity in mice}

The total extract up to $5000 \mathrm{mg} / \mathrm{kg}$ body wt did not show any signs of toxicity to mice and all the mice survived to the 28 days of observation period.

\section{Phytochemical Screening}

The results of phytochemical screening show that the $80 \%$ ethanol extract of Crassocephalum vitellinum contains tannins, saponins, flavonoids and triterpenes.

\section{Discussion}

The mechanism of ethanol gastric ulceration is due to direct toxic effect on the epithelium leading to necrotic lesions, depletion of gastric mucus which breaks the mucosal barrier, increase permeability of gastric mucosa leading to increased leakage of hydrogen ions from the lumen, back diffusion of acid, and decrease transluminal electrical potential difference [19-21]. Ethanol also causes changes in mucosal blood flow, destroy microvascular and nonvascular cells, mast cell degranulation, neutophil mediated mucosal injury, and depletion of certain oxygen free radical scavengers [22]. In addition to depletion of free radical scavengers, free radicals are released from the metabolism of ethanol [22], and this if further exacerbated by inhibition of the biosynthesis of cytoprotective prostaglandins [23].

In this study pantoprazole showed a clear protective action against acidified ethanol ulceration, probably suggesting the role of gastric acid in the acidified ethanol-induced gastric ulceration. Appearance of the pantoprazole treated rat gastric mucosa shows a big difference in gross appearance as compared to the solvent controls. On the other hand the aqueous ethanol extract of $C$. vitellinum, at $800 \mathrm{mg} / \mathrm{kg}$ body wt, conferred the same level of protection to the rat gastric mucosa (88.3\%) as $40 \mathrm{mg} / \mathrm{kg}$ body wt pantoprazole. An important question here is what is the basis for the protective action of the extract. Certainly there is no adequate evidence to allow us to suggest the mechanism of gastro-protection. The results of phytochemical screening showed that the extract of the aerial parts of C. vitellinum contains tannins, flavonoids and terpenoids which are phenolic compounds. Plant phenolic compounds are known to be antioxidants and free radical scavengers [24]. Owing to the established fact that ethanol-induced gastric ulceration is associated with

Table 1 Antiulcer activity of an $80 \%$ ethanol extract of aerial parts of $C$. vitellinum

\begin{tabular}{llll}
\hline Group No. & Dose of extract $\mathbf{( m g / k g}$ body $\mathbf{w t})$ & Mean ulcer index $(\mathbf{n}=\mathbf{6})$ & \% age protection \\
\hline $\mathbf{1}$ & Solvent control & 6 & 0 \\
$\mathbf{2}$ & 200 & $2.7 \pm 1.0$ & $55.0^{*}$ \\
$\mathbf{3}$ & 400 & $1.7 \pm 1.4$ & $71.7^{*}$ \\
$\mathbf{4}$ & 800 & $0.7 \pm 0.4$ & $88.3^{*}$ \\
$\mathbf{5 .}$ & $40 \mathrm{mg} / \mathrm{kg}$ body wt pantoprazole & $0.7 \pm 0.9$ & $88.3^{*}$ \\
\hline
\end{tabular}

Each value is a mean of results of 6 rats. ${ }^{*}=$ significant $P \leq 0.001$ compared to solvent controls. 

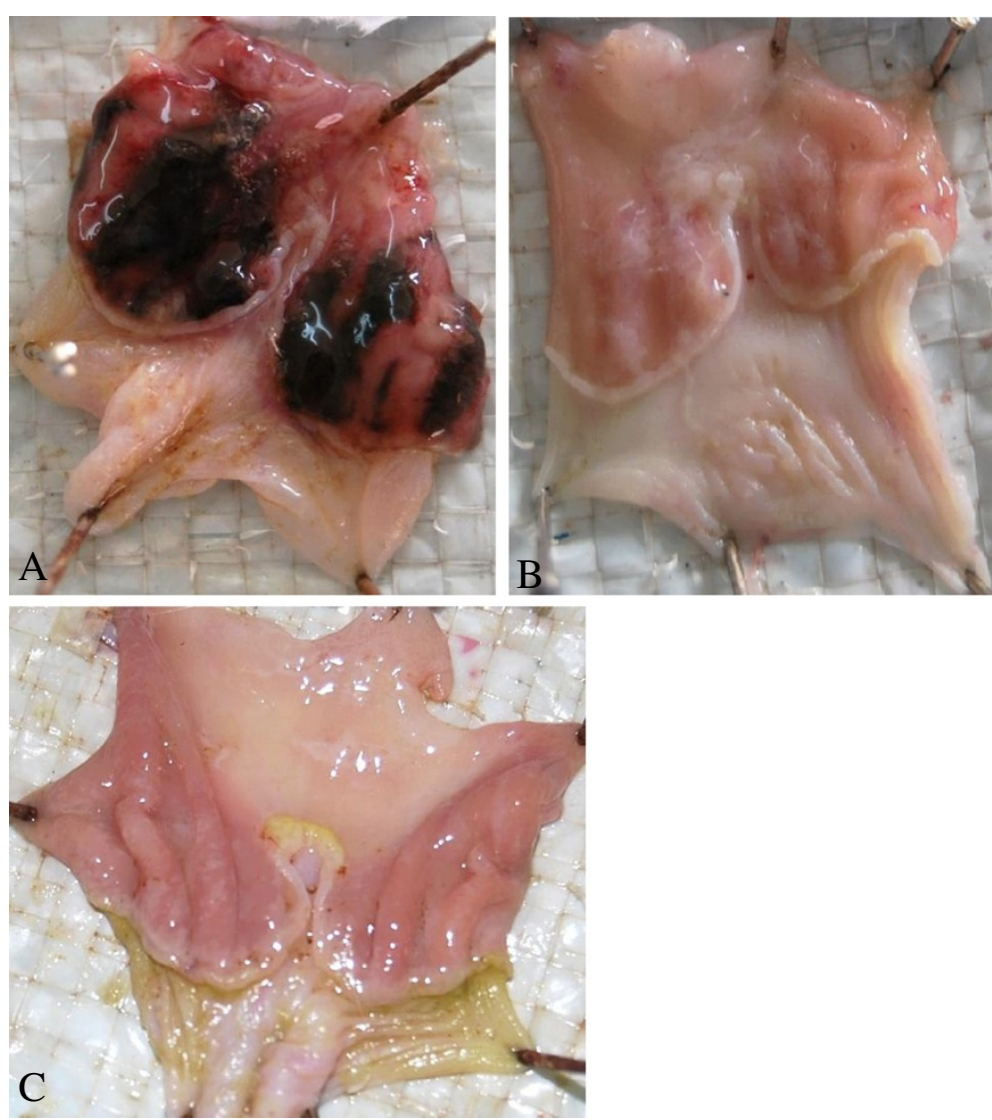

Figure 1 Photograph showing the stomach following insult with ethanol/HCl (80\%/5\%) mixture. In $(\mathbf{A})$ the rat was pre-dosed with the solvent before insult with ethanol/HCl mixture. In (B) the rat was pre-dosed with $800 \mathrm{mg} / \mathrm{kg}$ body wt of $80 \%$ ethanol extract of C. vitellinum before exposure to the ulcerative mixture and in (C) the rat was pre-dosed with $40 \mathrm{mg} / \mathrm{kg}$ body wt pantoprazole.

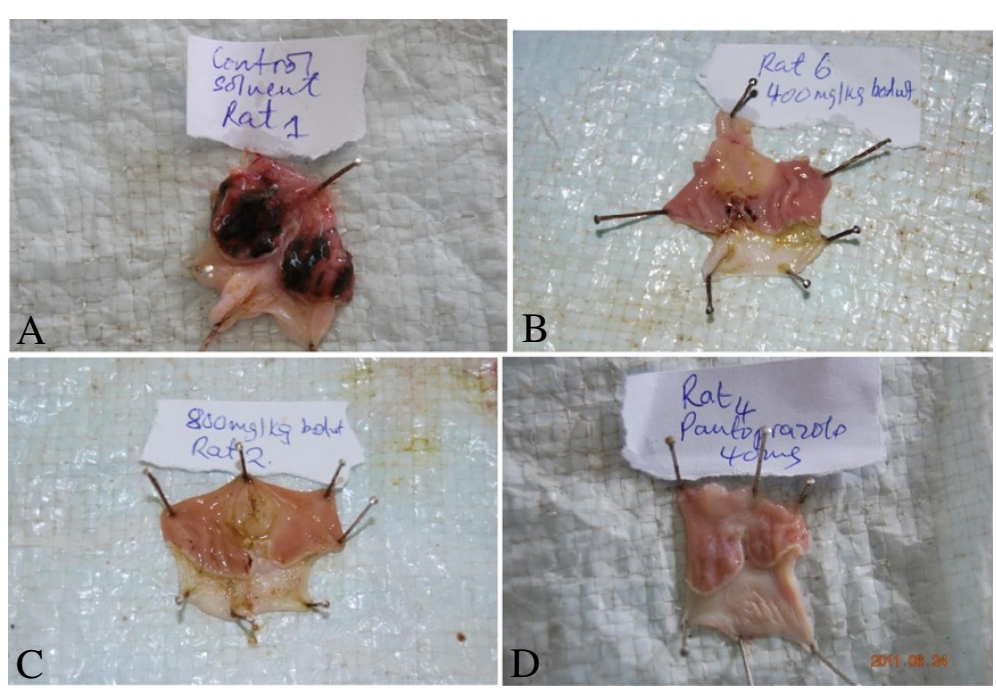

Figure 2 Photographs of rat gastric mucosa showing the dose-dependent effect of $C$. vitellinum against acidified ethanol ulceration of rat gastric mucosa. $\mathbf{A}=$ Solvent control; $\mathbf{B}=400 \mathrm{mg} / \mathrm{kg}$ body wt plant extract; $\mathbf{C}=800 \mathrm{mg} / \mathrm{kg}$ body wt plant extract; $\mathbf{D}=40 \mathrm{mg} / \mathrm{kg}$ body wt pantoprazole. 
Table 2 Antibacterial activity of ethyl acetate, DCM and aqeous fractions of C.vitellinum ethanol extract

\begin{tabular}{lllll}
\hline $\begin{array}{l}\text { Gram-ve } \\
\text { test isolates }\end{array}$ & \multicolumn{2}{l}{ MICs $(\mathbf{m g} / \mathrm{ml})$ of 80\% ethanol extract and its fractions } \\
\cline { 2 - 5 } & $\mathbf{8 0 \%}$ ethanol extract (total) & Ethyl acetate (fraction) & DCM (fraction) & Aqeous (fraction) \\
\hline K.pneumonea & - & 6.25 & 12.5 & 12.5 \\
S.typhii & 3.125 & 3.125 & 12.5 & 12.5 \\
E.coli & 3.125 & 3.125 & 6.25 & 6.25 \\
V.cholera & - & 3.125 & 12.5 & 12.5 \\
\hline
\end{tabular}

neutrophil mediated mucosal injury through the release of oxygen free radicals, proteases and lysosomal enzymes [22], there is a strong indication that the C. vitellinum extract owes its anti-ulcerogenic effect partly due to the presence of flavonoids, tannins and terpenoids which have antioxidant and free radical scavenging activity. The antioxidant properties of this plant have been reported in another study [4].

The $80 \%$ ethanol extract and its fractions exhibited some antibacterial activity against four Gram negative bacteria, which seems to be highest in the ethyl acetate fractions. It was intended to test the extracts for inhibitory effect against Helicobacter pylori which is implicated in peptic ulcer disease. However, it was not possible to get these organisms from any commercial source or through other laboratories. It was decided to test the extracts against the four enterobacteria to just get indicative results, but it does not mean in any way that getting positive results is a direct indication that the extracts would also automatically be active against $H$. pylori but does suggest that the extracts may be useful for treating other intestinal conditions related to infection by these bacteria. This notion is supported by some of the traditional medicine uses $[5,8,9]$.

The extract of $C$. vitellinum showed no significant changes in animal behavior or adverse signs of toxicity during post treatment evaluation of the mice following treatment with up to $5000 \mathrm{mg} / \mathrm{kg}$ body wt, thus suggesting that it is safe when administered acutely. Similar findings were observed in brine shrimp toxicity test in which both the total extract and its fractions showed minimal toxicity.

\section{Conclusion}

These results support the claim by traditional healers that the extract of the aerial parts of C.vitellinum has antiulcer activity. Since the dose conferring maximum protection is

Table 3 The effect $C$. vitellinum total extract and its fractions on brine shrimp toxicity

\begin{tabular}{|c|c|c|}
\hline Extracts & $\mathrm{LC}_{50}(\mu \mathrm{g} / \mathrm{ml})$ & $95 \% \mathrm{Cl}(\mu \mathrm{g} / \mathrm{ml})$ \\
\hline $80 \%$ ethanol extract & 37.49 & $27.98-50.16$ \\
\hline Aqueous fraction & 87.92 & $63.71-121.33$ \\
\hline Ethyl acetate fraction & 119.45 & $86.56-164.84$ \\
\hline Dichloromethane fraction & 88.79 & $69.37-113.65$ \\
\hline
\end{tabular}

very big it is unlikely that the results can have immediate clinical application. While it may be suggested that phenolic compounds contribute to the protective actions of the extract, there is need to do bioassay guided fractionation to identify active compound/s or fractions. The mechanism for the protective action also remains to be a subject for further studies.

\section{Abbreviations}

BST: Brine shrimp tests; Cl: Confidence interval; DMSO: Dimethylsulfoxide; $\mathrm{HCl}$ : Hydrochloric acid; INT: p-iodonitrotetrazolium; LC: Lethal concentration; MIC: Minimum inhibitory concentration; OECD: Organization for economic co-operation and development.

\section{Competing interests}

The authors have no competing interests for this research, and share the aspirations of the traditional healers of the Kagera Region to improve healthcare services in their community.

\section{Authors' contributions}

MJM did the ethnomedical studies that documented these plants and identified the plants for this study; participated in advising design of the study, provided support and guidance in the laboratory and provided the theoretical guidance of the project. He also drafted this manuscript. RSON participated in the experiments and was the laboratory supervisor for the study. He also participated in designing the study. EEH did some of the experiments, including preparation of the plant material, extraction, bioassays etc. under the guidance of RSON who worked closely with him in the laboratory. RLAM is a co-mentor of EEH and participated in advising design of the study and proposal development. AWK did phytochemical screening experiments and brine shrimp lethality experiments. All the authors read and approved the manuscript.

\section{Acknowledgements}

We are grateful to Mr. Didas Ngemera, the traditional healer who gave us this information, and Mr. Haji O. Selemani for collection and identification of the plant material. This study was partly funded by a grant to EEH from the Belgian Government under the umbrella of Belgian Technical Cooperation.

\section{Author details}

${ }^{1}$ Department of Biological and Preclinical Studies, Muhimbili University of Health and Allied Sciences, P.O. Box 65001, Dar es Salaam, Tanzania.

${ }^{2}$ Department of Medical Botany, Plant Breeding and Agronomy, Institute of Traditional Medicine, Muhimbili University of Health and Allied Sciences, P.O. Box 65001, Dar es Salaam, Tanzania.

Received: 11 March 2013 Accepted: 13 February 2014 Published: 19 February 2014

\section{References}

1. Moshi MJ, Otieno DF, Mbabazi PK, Weisheit A: The Ethnomedicine of the Haya people of Bugabo ward, Kagera Region, north western Tanzania. J Ethnobiol Ethnomed 2009, 5:24.

2. Ngari EW, Chiuri LW, Kairuki ST, Huckett S: Ethnomedicine of Ogiek of River Njoro watershed, Nakuru, Kenya. Ethnobatany Research and Application 2010, 8:135-152. 
3. Yamada T: A report on the ethnobotany of the Nyindu in the Eastern Part of the Former Zaire. Afr Study Monogr 1999, 20:1-72.

4. Mukazayire M-J, Allaeys V, Buc Calderon P, Stévigny C, Bigendako M-J, Duez P: Evaluation of the hepatotoxic and hepatoprotective effect of Rwandese herbal drugs on in vivo (guinea pigs barbiturate-induced sleeping time) and in vitro (rat precision-cut liver slices, PCLS) models. Exp Toxicol Pathol 2010, 62:289-299.

5. Mukazayire M-J, Minani V, Ruffo CK, Bizuru E, Stévigny CDP: Traditional phytotherapy remedies used in Southern Rwanda for the treatment of liver diseases. J Ethnopharmacol 2011, 138:415-431.

6. Mukazayire M-J, Allaeys V, Buc Calderon P, Stévigny C, Bigendako M-J, Duez P, Alphonce N, Bigendako MJ, Fawcett K, Yonsheng G: Ethnobatanic study around volcanoes National Park of Rwanda. New York Sci J 2010, 3:37-49.

7. Kayonga AHF: National University Research Center on Pharmacopoeia and Traditional Medicine Curfametra. Traditional medicine and Rwandan medicinal palnts. In Contribution to ethnobotanic study of Rwandan flora. Gisenyi Prefecture. ; 1987:121.

8. Dasetour S: Human and veterinary Pharmacopoiea of Rwanda. 1991, 22:252. Institute of Scientific Research. Butare -Republic of Rwanda. Royal Museum of Central Africa, Tervuren, Belgium.

9. Nsanzimana J: Therapeutic potential of some Rwandese medicinal plants for animal diseases. In Dissertation submitted in partial fulfulment for requirement of award of Bachelor of Biology degree, Department of Biology, National University of Rwanda. ; 2011:7-15.

10. Mukazayire MJ, Tomani JC, Okusa PN, Chalchat JC, Stévigny C, Duez P: Chemical composition and evaluation of antioxidant and antimicrobial properties of Ocimum lamiifolium and Crassocephalum vitellinum essential oils. Planta Med 2011, 74:116.

11. Ramathal DCNO: Medicinal plants used by Rwandese traditional healers in refugee camps in Tanzania. Pharm Biol 2001, 39:132-137.

12. Shay H, Komarov SA, Fels SS, Meranze D, Gruenstein M, Siplet H: A simple method for the uniform production of gastric ulceration in the rat. Gastroenterology 1945, 5:43-61.

13. Ellof J: A quick Microplate Method to Determine the Minimum Inhibitory Sensisitive and Concentration of Plant Extracts for Bacteria. Planta Med 1998, 64:711-713.

14. Meyer BN, Ferrigni NR, Putnam JE, Jacobsen LB, Nichols DE, McLaughlin JL: Brine shrimp: a convenient general bioassay for active plant constituents. Planta Med 1982, 45:31-34.

15. Litchfield JT, Wilcoxon F: A simplified method of evaluating dose-effect experiments. J Pharmacol Exp Ther 1949, 96:99-138.

16. OECD Guidelines for Testing Chemicals Section 4: Health Effects - Test No. 425: Acute Oral Toxicity: Up-and-Down Procedure. :. OECD Publication Date: 16 Oct 2008 Pages :27 ISBN :9789264071049 (PDF) DOI :10.1787/ 9789264071049-en.

17. Harbone JB: Phytochemical Methods - A Guide to Modern Techniques of Plant Analysis. London: Chapman and Hall; 1998:182-190.

18. Owonubi OO, Emmanuel SA: Phytochemical screening: Nigerian medicinal plants. Lloydia 1978, 41:234-235.

19. Ramesh A, Alekhya N, Lohitha I: Antiulcer activity of Eugenia jambolana leaves against ethanol induced gastric ulcer in albino rats. Int I Pharm Res Dev 2011, 3:106-112.

20. Jian-Hui X, Yun-Long C, Qing-He W, Jun W, Ji-Yan S, Hong-Yin C, Yu-Cui L, Yi-Sheng L, Jin-Bin L, Xiao-Ping L, Ping H, Zi-Ren S: Gastroprotective and anti-Helicobacter pylori potential of herbal formula HZJW: safety and efficacy assessment. BMC Complement Altern Med 2013, 13:119.

21. Klein-Júnior LC, Santin JR, Lemos M, Silveira AC, Rocha JA, Beber AP, Wagner TM, Bresolin TM, Bella-Cruz A, Cechinel-Filho V, Faloni de Andrade S: Role of gastric mucus secretion, oxinitrergic system and sulfhydryl groups on the gastroprotection elicited by Polygala cyparissias (Polygalaceae) in mice. J Pharm Pharmacol 2013, 65:767-776.

22. Mizui T, Shimono N, Doteuchi M: A possible mechanism of protection by polyamines against gastric damage induced by acidified ethanol in rat polyamine protection may depend on the anti-peroxidative properties. Jpn J Phamacol 1987, 44:43-50.

23. Nasuti C, Gabbianelli R, Falcioni G, Cantalamessa F: Antioxidative and gastroprotective activities of anti-inflammatory formulations derived from chestnut honey in rats. Nutr Res 2006, 13:130-137.

24. Polterait O: Antioxidants and free -radical scavengers of natural origin. Curr Org Chem 1997, 1:415-440.

doi:10.1186/1756-0500-7-91

Cite this article as: Moshi et al: Antimicrobial activity, acute toxicity and cytoprotective effect of Crassocephalum vitellinum (Benth.) S. Moore extract in a rat ethanol-HCl gastric ulcer model. BMC Research Notes 2014 7:91.

\section{Submit your next manuscript to BioMed Central and take full advantage of:}

- Convenient online submission

- Thorough peer review

- No space constraints or color figure charges

- Immediate publication on acceptance

- Inclusion in PubMed, CAS, Scopus and Google Scholar

- Research which is freely available for redistribution

Submit your manuscript at www.biomedcentral.com/submit
() Biomed Central 